\title{
KEMANDIRIAN FISKAL DAERAH OTONOMI: KESIAPAN DAERAH DALAM PELIMPAHAN KEWENANGAN PENGELOLAAN PAJAK BUMI DAN BANGUNAN PERKOTAAN DAN PERDESAAN
}

\author{
Lastria Nurtanzila ${ }^{1}$
}

\begin{abstract}
Financially independent for a region is a must in decentralization era. This article try to examine how central and local government push their effort to make a region financially independent. One of the policy agenda is to delegate the authority to manage property tax from central government to local government. Based on Law Number 28/ 2009, property tax becomes the authority of local government, this is a very good news to increasing local revenue. The increasing of local revenue is expected to increasing local government capacity to funding their activity. Nevertheless, local government readiness becomes a big issue, known that until 2013 only 123 kabupaten/kota that already implemented this policy, where the rest of the kabupaten/kota are still not ready to implement it. But, the current issue is the capacity of readiness, not all of the kabupaten/kota has the capicity and capability to implement the policy. Therefore, this policy needs to be reck by central government, so in the future this policy can be a good instrument to made region financially independent.
\end{abstract}

Keywords: Financially Independent, Decentralization, and Property Tax

\begin{abstract}
ABSTRAK
Kemandirian fiskal di daerah otonomi merupakan aspek penting dalam kajian desentralisasi. Penelitian ini mencoba mengkaji hubungan pemerintah pusat dan pemerintah daerah dalam mengupayakan kemandirian fiskal daerah. Peraturan mengatur bahwa pendapatan pajak dari sektor PBB akan menjadi pajak daerah, dengan demikian diharapkan agar pendapatan ini dapat menambah PAD dan meningkatkan alokasi dana untuk pembiayaan daerah itu sendiri. Kesiapan daerah menjadi isu yang cukup serius. Hingga tahun 2013 masih ada 123 kabupaten/kota yang menjalankan kebijakan ini, sementara 369 sisanya masih diproyeksikan untuk dapat melaksanakannya pada tahuntahun berikutnya. Sementara menilik dari hasil kualitas pelaksanaan masih banyak daerah yang menyatakan belum siap baik dari segi SDM, infrastrutur, maupun kondisi masyarakat. Sehingga kebijakan ini butuh mendapatkan perhatian lebih melihat impact dari pelimpahan kebijakan ini nantinya pada peningkatan kemandirian fiskal daerah.
\end{abstract}

KataKunci: Desentralisasi, Kemandirian Fiskal, Pajak Bumi dan Bangunan.

\footnotetext{
${ }^{1}$ Dosen, Sekolah Vokasi, Universitas Gadjah Mada. email: lastrianurtanzila@ugm.ac.id.
} 


\section{PENDAHULUAN}

Desentralisasi telah menjadi trend global sekaligus kebutuhan masyarakat dunia untuk mempunyai hak yang lebih besar dalam menentukan nasibnya dan berpengaruh secara lebih besar dalam pemerintahan. Banyak negara demokrasi yang melakukan devolusi politik, fiskal, dan kekuasaan administratif ke pemerintah lokal yang bertujuan untuk mencoba melakukan transfer kewenangan dan tanggung jawab dari pusat ke daerah untuk mencapai kemandirian daerah.

Ada dua tujuan yang ingin dicapai melalui kebijakan desentralisasi, yaitu tujuan politik dan tujuan administratif. Tujuan Politik yaitu untuk memposisikan Pemda sebagai media pendidikan politik bagi masyarakat di tingkat lokal dan secara nasional untuk mempercepat terwujudnya civil society. Sedangkan tujuan administratif yaitu untuk memposisikan Pemda sebagai unit pemerintahan di tingkat lokal yang berfungsi untuk menyediakan pelayanan masyarakat secara efektif dan ekonomis. Senada dengan apa yang diungkapkan diatas, desentralisasi tidak lagi hanya menjadi sebatas pengalihan kewenangan namun juga sekaligus kewenangan di bidang fiskal.
Otonomi meliputi otonomi di bidang penganggaran, atau sering juga disebut sebagai desentralisasi fiskal. Wacana mengenai otonomi daerah sendiri sesunguhnya sudah berkembang cukup lama namun baru mulai terorganisir dengan baik setelah dirumuskannya UU Nomor 25 Tahun 1999 dan UU Nomor 22 Tahun 1999. Desentralisasi fiskal adalah salah satu perubahan penting dimana pemerintah daerah diberikan keleluasaan dalam menetapkan anggaran daerah melalui APBD.

Di lain pihak, UU Nomor 17 Tahun 2003 tentang Keuangan Negara menetapkan prestasi kerja yang akan dicapai sebagai dasar penyusunan RKA baik di tingkat pusat (APBN) maupun daerah (APBD). Wacana otonomi daerah yang sudah cukup lama itu mendorong terjadinya berbagai revisi terhadap kesesuaian konten dan konteks kebijakan pada masa sekarang. Oleh karena itulah, diterbitkan UU Nomor 32 Tahun 2004 yang secara tidak langsung telah mengadakan perubahan yang sangat mendasar terhadap sistem administrasi pemerintahan dan keuangan daerah.

Dewasa ini, pemerintah mengubah kebijakan anggaran dari yang berbasis resourceske anggaran yang berbasis 
pajak. Hal ini dilatarbelakangi oleh semakin menipisnya sumber daya alam yang dimiliki seperti migas. Selain itu, ketergantungan kepada harga pasar internasional yang fluktuatif menjadi hal yang menyulitkan untuk dijadikan referensi dalam upaya membangun anggaran yang stabil dan dinamis. Untuk itu, peran pajak secara bertahap menjadi semakin penting, dan pada posisi yang menentukan dalam pos penerimaan APBN.

Pajak merupakan sumber dana yang berasal dari dalam negeri dalam upaya mewujudkan kemandirian suatu bangsa atau negara dalam pembiayaan pembangunan yang berguna untuk kepentingan bersama. Oleh karena itu, pajak yang didalamnya termasuk Pajak Bumi Bangunan (PBB) adalah tulang punggung penerimaan negara guna mencapai kemandirian pembangunan. Di samping itu, pajak merupakan wujud partisipasi masyarakat dalam pembangunan. Sebagaimana Mardiasmo (2006:11), pemungutan pajak merupakan perwujudan dari pengabdian dan peran serta wajib pajak untuk secara langsung bersama-sama melaksanakan kewajiban perpajakan yang diperlukan untuk pembiayaan negara dan pembangunan nasional. Untuk itu, penerimaan pajak memerlukan partisipasi dari masyarakat untuk membayar pajak secara jujur dan benar sesuai dengan kaidah menetapkan pajak sendiri (self assessment).

Berdasarkan UU Nomor 28 Tahun 2009, tentang Pajak dan Retribusi, pajak daerah yang selanjutnya disebut pajak adalah kontribusi wajib kepada daerah yang terutang oleh orang pribadi atau badan yang bersifat memaksa berdasarkan undang-undang, dengan tidak mendapatkan imbalan secara langsung dan digunakan untuk keperluan daerah, bagi sebesar-besarnyakemakmuran rakyat. Sementara retribusi adalah pungutan daerah sebagai pembayaran atas jasa atau pemberian izin tertentu yang khusus disediakan dan/atau diberikan oleh pemerintah daerah untuk kepentingan orang pribadi atau badan.

Perbedaan yang mendasar dari Undang-undang Nomor 28 Tahun 2009 dengan UU tentang PDRD yang lama (UU No.34 Tahun 2000) adalah sistemnya. Di UU PDRD baru, sistem yang ditentukan adalah tertutup yang berarti pemerintah daerah (pemda) tidak bisa menambahkan jenis pajak dan retribusi baru sesuai dengan potensi daerah. Sedangkan di UU No.34 Tahun 2000, sistem yang ditetapkan adalah sistem terbuka yang berarti pemerintah kabupaten dan kota 
dibebaskan untuk menentukan jenis pajak dan retribusi lain (open list) di luar yang sudah ditetapkan. Syaratnya antara lain, penentuan tersebut harus sesuai dengan potensi pajak dan retribusi di daerah. Selain itu, tidak bertentangan dengan yang menjadi kewenangan pusat dan provinsi serta tidak menimbulkan dampak negatif.

Selama ini pungutan Daerah yang berupa pajak dan retribusi diatur dalam UU Nomor 18 Tahun 1997 tentang Pajak Daerah dan Retribusi Daerah sebagaimana telah diubah dengan Undang-Undang Nomor 34 Tahun 2000. Sesuai dengan Undang-Undang tersebut, daerah diberi kewenangan untuk memungut 11 jenis pajak, yaitu 4 jenis pajak provinsi dan 7 jenis pajak kabupaten/kota. Selain itu, daerah juga diberi kewenangan untuk menentukan jenis pajak lainnya selama masih memenuhi kriteria yang ditetapkan dalam undang-undang.

Penarikan jenis-jenis pajak lain yang diperbolehkan selama sesuai dengan kriteria undang-undang tersebut diharapkan dapat menutup pengeluaran daerah. Namun pada kenyataannya tidak demikian. Di beberapa daerah, hampir semua pungutan baru tersebut berdampak tidak baik pada iklim investasi. Hal tersebut dikarenakan banyaknya pungutan daerah yang dapat menyebabkan biaya tinggi, karena saling tumpang tindih dengan pungutan pusat. Hal ini dapat menyebabkan arus distribusi barang dan jasa menjadi terhambat.

Dalam rangka meningkatkan posisi otonomi daerah dan desentralisasi fiskal di Indonesia, maka sejak tanggal 1 Januari 2011, PBB P2 (Pajak Bumi dan Bangunan Perdesaan dan Perkotaan) serta BPHTB (Bea Perolehan Hak atas Tanah dan Bangunan) menjadi pajak daerah (kabupaten/kota). Khusus mengenai BPHTB sudah mulai efektif berlaku sejak tanggal 1 Januari 2011, sementara PBB diberi masa transisi sampai dengan tanggal 1 Januari 2014 (Santosa: 2011).

Alasan mengapa kedua jenis pajak ini menjadi pajak daerah karena mememenuhi syarat antara lain ditinjau dari aspek lokalitas, hubungan antara pembayar pajak dan yang menikmati manfaat pajak, serta di berbagai negara kedua jenis pajak tersebut telah menjadi pajak daerah.

Bagi daerah yang belum memiliki Perda tentang BPHTB, pemerintah daerah dan DPRD harus segera menyusunnya agar tidak terjadi hambatan dan pelanggaran hukum. Sementara bagi daerah yang belum memiliki Perda tentang PBB juga diharapkan segera 
merealisasikannya, meskipun waktu yang dimiliki masih 3 tahun lagi, namun infrastruktur dan materi dari daerah harus disiapkan sejak sekarang.

Selama Perda PBB belum ditetapkan maka PBB masih menjadi pajak pusat, dimana $90 \%$ dari penerimaan dibagihasilkan kepada daerah, yaitu $16,2 \%$ untuk daerah yang bersangkutan; $64,8 \%$ untuk daerah kabupaten/kota yang bersangkutan; dan $9 \%$ untuk biaya pemungutan. Sebesar $10 \%$ dari penerimaan PBB dibagikan kepada seluruh kabupaten/kota dengan imbangan $65 \%$ dibagikan secara merata dan $35 \%$ dibagikan sebagai insentif kepada kabupaten/kota yang melampaui target penerimaan (Santosa : 2011).

Dalam hal mencapai kemandirian daerah, tiap daerah memiliki peran untuk mengupayakan kemandirian tersebut. Setiap Provinsi dapat dianalisis terkait pencapaian dan perkembangan kemandirian fiskal daerahnya.

Berdasarkan UU Nomor 32 Tahun 2004, otonomi daerah lebih diletakkan pada tingkat kabupaten/kota dimana satuan tersebut dianggap sebagai satuan pemerintah yang paling dekat dengan masyarakat, sehingga kabupaten/kota menjadi salah satu tumpuan otonomi daerah dalam mencapai kemandirian fiskal.

Kesiapan nasional menerima kebijakan ini perlu dikaji secara mendalam. Setiap kabupaten/kota memiliki kepasitas dan kapabilitasnya masing-masing dalam mengembangkan potensi daerah yang ada untuk diolah menjadi pendapatan daerah. Persiapan yang memadai menjadi tanggung-jawab pusat dan berkoordinasi dengan daerah. Banyak kebijakan yang berakhir dengan kebijakan sentralistik, dimana terjadi pemaksaan untuk melaksanankan suatu kebijakan dari pusat tanpa ada kesiapan dari daerah. Oleh karena itu, perlu dilakukan pemaparan fenomena kesiapan daerah untuk pelaksanaan kebijakan pelimpahan kewenangan pengelolaan PBB Perkotaan-Pedesaan menjadi pajak daerah.

\section{METODE}

Penelitian ini menggunakan metode kajian pustaka atau sering dikenal juga dengan studi literatur. Dalam studi literatur, pendekatan yang digunakan cenderung pada pendekatan aliran kualitatif sehingga arahan penelitian lebih kepada menemukan sesuatu yang baru dengan melalui berbagai kajian teori dari 
berbagai literatur. Kajian teoritis yang ada didukung dengan beberapa data empiris dan dielaborasikan untuk mencapai suatu gagasan tentang kesiapan kemandirian fiskal di daerah otonom.

\section{HASIL DAN PEMBAHASAN}

\section{Kesiapan Daerah dalam Pelimpahan}

\section{Kewenangan Pengelolaan PBB}

PBB merupakan pajak yang potensial dan biladikaitkan dengan objek yang dikenakan pajak, maka pajak ini bersifat tetap dan tidak berubah-ubah. Selain itu, pajak ini merupakan wilayah dari suatu daerah. Menurut Kelly (1989), PBB dapat juga memperkuat peranan pemerintah daerah karena membuka peluang dasar penarikan pajak yang lebih luas bagi penerimaan pemerintah sendiri. PBB yang efektif akan menciptakan sumber penerimaan yang kuat bagi pemerintah daerah dan memperkecil kebutuhan akan bantuan dari pemerintah pusat. Dengan demikian, pemerintah daerah dapat memperluas kewenangannya untuk mengelola daerah-nya sendiri sesuai dengan prinsip-prinsip otonomi daerah.

Menurut Mardiasmo (2004) hak pemerintah daerah dari hasil penerimaan PPh Perseorangan adalah sebesar 20\% dan PBB sebesar 90\%, sedangkan BPHTB sebesar $80 \%$ dari penerimaan. Selama ini penerimaan dari ketiga jenis pajak ini disebut sebagai penerimaan transfer dari pemerintah pusat jenis bagi hasil pajak.

Kontribusi PBB sangat berarti dan tidak mungkin dihilangkan meskipun jumlahnya tidak terlalu besar dalam struktur penerimaan negara. Seperti diungkapkan Brotodiharjo (2003: 220), bahwa sekecil apapun jumlah uang yang akan dapat masuk kedalam kas negara, uang itu selalu dapat digunakan sebagai sumbangan untuk menutupi biaya-biaya pemerintahan.

Menurut Kelly (1989: 120), PBB merupakan cara menghimpun dana yang disukai, karena alasan-alasan berikut:

1. Pemilik tanah menarik manfaat dari investasi pemerintah dalam layanan masyarakat dan prasarana. Oleh karena itulah pemilik tanah harus membayar pajak sebagai kontrapresatasi dari manfaat yang diperolehnya.

2. PBB dapat dijadikan sebagai garis pertahanan kedua karena banyak orang yang berhasil menghindari pajak pendapatan.

3. Penetapan PBB tidak sesulit pajak pendapatan atau pajak-pajak lain karena objek PBB tampak dan tidak bergerak. 
4. PBB dapat menjadi sumber

Dalam Makalah

Seri penerimaan yang besar, stabil dan Desentralisasi Fiskal yang diterbitan ADB elastisjika dirancang dengan baik. pada tahun 2010, menyatakan bahwa Kadar elastisitas tersebut tergantung negara-negara yang memiliki infrastruktur pada seberapa jauh tanah legislatif yang baik; hukum perundangan bersangkutan dapat ditaksir dengan teratur dan dapat dinilai menurut harga pasar yang berlaku.

5. PBB dapat juga memperkuat penerimaan pemerintah daerah karena membuka peluang dasar pajak yang lebih luas bagi penerimaan pemerintah daerah sendiri. agraria yang baik; sistem pertanahan yang baik; sistem teknologi informasi yang maju; mewakili suatu idealisme yang jauh berbeda dengan negara-negara berkembang yang belum memiliki sistem informasi pertanahan yang terpadu. Bahkan dibeberapa daerah tidak semua PBB dipungut dan dikelola oleh pemerintah daerah.

6. PBB juga dapat membantu mengurangi spekulasi tanah dan mendorong pemilik tanah menjaga miliknya sebaik-baiknya.

Tabel 1. Kebijakan Penetapan Pajak pada Umumnya (di seluruh dunia)

\begin{tabular}{|c|c|c|}
\hline Pusat Negara & Bagian/Provinsi & Kabupaten/Kota \\
\hline $\begin{array}{l}\text { 1. Pajak atas faktor-faktor } \\
\text { yang bergerak: } \\
\text { penerimaan perorangan } \\
\text { dan perusahaan, pajak- } \\
\text { pajak penjualan yang } \\
\text { bertahap seperti PPN. } \\
\text { 2. Pajak-pajak untuk } \\
\text { memajukan tujuan } \\
\text { nasional. } \\
\text { 3. Pajak progresif yang } \\
\text { dapat didistribusikan } \\
\text { ulang. }\end{array}$ & $\begin{array}{l}\text { 1. Pajak berbasis domisili: } \\
\text { pajak dan bea } \\
\text { penjualan, cukai atau } \\
\text { pajak "dosa" (seperti } \\
\text { rokok, minuman keras, } \\
\text { judi, dll) } \\
\text { 2. Beban manfaat: gaji, } \\
\text { kendaraan survey dll. } \\
\text { Pajak pendaftaran } \\
\text { usaha, royalti dan bea } \\
\text { sumberdaya, biaya } \\
\text { pengadilan dan } \\
\text { materai, dll. }\end{array}$ & $\begin{array}{l}\text { 1. Pajak bumi dan } \\
\text { bangunan } \\
\text { 2. Pajak jalanan (frontage } \\
\text { tax) } \\
\text { 3. Jalan tol setempat } \\
\text { 4. Pajak festival dan pasar } \\
\text { 5. Pajak pemilih } \\
\text { 6. Biaya pengguna. }\end{array}$ \\
\hline
\end{tabular}

Sumber : Anwar Syah (1994) The Reform Of Intergovernmental Fiscal Relations In Developing And Emerging Market Economices. The World Bank's Policy and research series No. 23, h.2, p.2. dalam Makalah Seri Desentralisasi Fiskal di Indonesia, ADB (2010) 
Kebijakan penetapan pajak memiliki dua prinsip utama yang mendasar yaitu adanya kebutuhan fiskal dan efisiensi administrasi.Tren menunjukkan bahwa PBB menjadi pajak daerah di banyak negara di seluruh dunia. Asumsi yang berkembang adalah banyak negara tersebut memahami dan mengaharapkan bahwa PBB dapat menjadi sumber penerimaan yang signifikan bagi pemerintah daerah.

Meskipun tidak ada alasan empiris untuk mengharapkan bahwa PBB dapat sepenuhnya mendanai kebutuhankebutuhan pemerintahan daerah, namun PBB dapat mendanai secara signifikan kebutuhan tersebut bahkan hampir sebagian besar. Hal ini tentu saja dapat dicapai apabila suatu negara tersebut telah memiliki sistem informasi pertanahan yang canggih dan terpadu sehingga segala proses pengelolaan dapat secara efisien.

Kanada merupakan salah satu contoh negara yang memiliki tiga tingkat pemerintahan (federal, provinsi, dan kotapraja)yang praktek pengenaan PBB dilakukan sebagian besar oleh pemerintah kabupaten/kotapraja. Bahkan dalam berbagai kesempatan penetapan batas PBB tertentu yang dilakukan oleh provinsi atau lembaga pendanaan sekolah setempat, biasanya diserahkan kepada pemerintahan kotapraja untuk berperan sebagai administrator dari program semacam itu.

Situasi serupa terjadi di Australia yang merupakan negara maju dengan pasar properti yang maju pula. Negara ini juga memiliki informasi jual-beli yang transparan yang mempermudah dalam menilai secara akurat daripada di wilayah yang memiliki pengetahuan pasar dan transparansi yang jauh lebih sedikit, seperti Indonesia.

Dari berbagai pengalaman yang ada di dunia internasional, desentralisasi atas semua fungsi pajak sebaiknya dilakukan secara bertahap berdasarkan kapasitas. Kapasitas tersebut dihasilkan dari individu yang cukup termotivasi dan terampil, dan dapat bekerja efektif dalam budaya organisasi yang ada.

Menurut hasil kajian ADB (2010), pada umumnya kapasitas pemungutan dapat dikembangkan jauh lebih pesat daripada kapasitas assesment, karena kapasitas assesment membutuhkan kemampuan dan keterampilan yang lebih tinggi dan pasar properti yang memang sudah berfungsi dengan baik. 
Di Indonesia,terutama di luar Jakarta, kedua prasyarat untuk memiliki kemampuan assessmentperlu dikembangkan meskipun memerlukan waktu bertahun-tahun. Oleh karena itulah, kapasitas pungutan lebih ditekankan karena kapasitas assesment membutuhkan waktu lebih lama.

Dalam kasus di berbagai negara, masih banyak yang beranggapan bahwa melakukan pemisahan antara kedua kapasitas adalah jalan yang terbaik, misalnya pemerintah daerah melakukan pemungutan sementara asssesmentmasih dibawah kewenangan pusat,lalu dilimpahkan secara bertahap dari pemerintah pusat ke kota-kota besar. Namun, tidak mungkin semua fungsi dilimpahkan kepada pemerintah daerah di Indonesia karena kondisi yang sangat beragam di negara sebesar Indonesia. Oleh karena itu, pendekatan simetris sangat relevan.

Di beberapa kasus, pemerintah pusat menyediakan jasa sehingga pemerintah daerah seharusnya membayar mereka untuk persiapan kadaster fiskal. Sementara struktur biaya sangat bervariasi antara setiap negara, dari beberapa pengalaman internasional, meunrut data ADB (2010) sekitar 0,5\% sampai $2 \%$ harus dikeluarkan oleh pemerintah daerah untuk menutup kadaster fiskal tersebut. Namun, penerimaan lain yang nantinya akan meningkat digunakan untuk melembagakan proses-proses pembangunan, memperbaiki informasi pasar, penguatan properti dan penguatan sitem informasi pertanahan. Sementaradi Indonesia sendiri, Dirjen Pajak menetapkan tarif resmi sebesar 9\% yang mana dinilai terlalu tinggi

Dengan adanya pelajaran dari berbagai pengalaman internasional, maka Indonesiaharus menjalankan proses desentralisasi PBB, meskipun hal tersebut tidak boleh dinggap ringan. Pemikiran dan ketrampilan sangat diperlukan untuk mengubah status quo yang ada saat ini. Kompetensi yang dibutuhkan untuk pengelolaan pajak ini mungkin ada di pusat, namun tidak mustahil bisa mengundang para ahli internasional untuk memberikan wawasan tentang sistem informasi pertanahan yang maju, sehingga permassalahan property tax dapat diatasi dan dapat menjadi solusi bagi kemandirian fiskal daerah otonom di Indonesia.

Setelah adanya UU Nomor 28 Tahun 2009, pendaerahan PBB sebagai 
bagian dari desentralisasi fiskal menjadi harapan dalam meluaskan sumbersumber penerimaan daerah, sehingga setiap daerah dapat mempercepat pembangunannya didasarkan pada penerimaan yang lebih baik. Perubahan kebijakan PDRD terhadap pengelolaan PBB, dapat dilihat dalam Tabel 2.

Tabel 2. Perubahan Kebijakan PDRD terhadap Pengelolaan PBB P2

\begin{tabular}{|c|c|}
\hline Sebelum Perubahan Kebijakan PDRD & Sesudah Perubahan Kebijakan PDRD \\
\hline 1. PBB P2 ditetapkan sebagai pajak pusat & $\begin{array}{l}\text { 1. PBB P2 ditetapkan sebagai pajak } \\
\text { daerah }\end{array}$ \\
\hline $\begin{array}{l}\text { 2. Kebijakan PBB-P2 ditetapkan oleh } \\
\text { pusat. }\end{array}$ & $\begin{array}{l}\text { 2. Kebijakan PBB P2 ditetapkan oleh } \\
\text { Daerah. }\end{array}$ \\
\hline $\begin{array}{l}\text { 3. Penerimaan PBB-P2 dibagi-hasilkan, } \\
\text { dengan imbangan: } \\
\text { a. } 90 \% \text { bagian daerah: } \\
-16,2 \% \text { untuk provinsi } \\
-64,8 \% \text { untuk kabupaten/kota } \\
-9 \% \text { biaya pemungutan } \\
\text { b. } 10 \% \text { bagian pusat, dibagikan } \\
\text { kepada: } \\
\text { - } 65 \% \text { dibagikan merata ke } \\
\text { seluruh kabupaten/kota } \\
\text { - } 35 \% \text { dibagikan sebagai insentif } \\
\text { kepada kabupaten/kota yang } \\
\text { melampaui target penerimaan. }\end{array}$ & $\begin{array}{l}\text { 3. Daerah dapat tidak memungut pajak } \\
\text { daerah apabila : } \\
\text { a. Potensi tidak memadai } \\
\text { b. Disesuaikan dengan kebijakan } \\
\text { daerah. }\end{array}$ \\
\hline $\begin{array}{llrr}\text { 4. } & \text { PBB P2 yang dibagihasilkan } & \text { kepada } \\
\text { daerah tidak termasuk } & \text { dalam } \\
\text { komponen PAD } & & \end{array}$ & $\begin{array}{l}\text { 4. Seluruh penerimaan PBB P2 menjadi } \\
\text { PAD. Sehingga masyarakat daerah } \\
\text { terlibat dalam proses perumusan } \\
\text { kebijakan PBB P2 dan dapat } \\
\text { mengontrol } \\
\text { penerimaannya. }\end{array}$ \\
\hline $\begin{array}{l}\text { 5. Daerah tidak memiliki tanggungjawab } \\
\text { atas optimalisasi pemungutan PBB P2. }\end{array}$ & $\begin{array}{l}\text { 5. Daerah bertanggung-jawab sepenuhnya } \\
\text { atas pemungutan PBB P2, baik secara } \\
\text { legal, operasional, dan pemanfaatan. }\end{array}$ \\
\hline
\end{tabular}

Sumber: Modul Sosialisasi Pengalihan PBB-P2 dan BPHTB menjadi Pajak Daerah, Direktorat Pajak Daerah dan Retribusi Daerah, Kementrian Keuangan Republik Indonesia 2011 (diolah). 
Tahap persiapan untuk melaksanakan kebijakan pendaerahan ini diatur sesuai dengan Peraturan Direktur Jenderal Pajak Nomor Per-61/Pj/2010 tentang Tata Cara Persiapan Pengalihan Pajak Bumi Dan Bangunan Perdesaan Dan Perkotaan Sebagai Pajak Daerah. Diantaranya mengatur tentang persiapan yang harus dilakukan daerah baik secara teknis maupun subtantif.Menurut Direktorat Jendral Pajak Departemen Keuangan Republik Indonesia, terdapat beberapa hal yang perlu disipakn daerah terkait dengan pendaerahan PBB, yaitu:

1. Peraturan yang terkait dengan pengelolaan PBB Perdesaan dan Perkotaan.

2. Sumberdaya manusia. Pendidikan dan pelatihan pegawai.

3. Sarana dan prasarana. Perangkat lunak dan keras serta sarana pendukung lainnya.

4. Kerjasama semua pihak yang terkait. Yaitu instansi-instansi terkait seperti Departemen Dalam Negeri, Pemerintah Daerah Kabupaten/Kota, dan Departemen Keuangan (DJPK, DJP)

Selain itu Departemen Keuangan juga mempersiapkan tahapan tentatif persiapan pengalihan PBB Pedesaan dan
Perkotaan, yang dibagi dalam beberapa tahap berikut:

1. Tahap Persiapan (Maret-Juni 2010) terdiri dari:
a. Sosialisasi (wajib pajak dan stakeholders)
b. Pemeliharaan database
c. Menyiapkan aplikasi SISMIOP
d. Inventarisasi peraturan dan SOP PBB Pedesaan dan Perkotaan
e. Trainning PBB Pedesaan dan Perkotaan.

2. Tahap Pengalihan (Juli-November 2010) terdiri dari:

a. Koordinasi dengan instansi terkait.

b. Seremonial dan berita acara penyerahan basis data, peta, aplikasi SISMIOP, dan tunggakan PBB Pedesaan dan Perkotaan.

c. Penyelesaian trainning.
d. Serah terima dan memberi waktu yang cukup untuk pengalihan.

3. Tahap paska Pengalihan (JanuariDesember 2011). Terdiri dari:
a. Konseling peraturan dan SOP
b. Konseling aplikasi SISMIOP
c. Konseling pendataan
d. Konseling penilaian 
e. Konseling keberatan dan banding

f. Konseling pelayanan.

Dalam pengelolaan Pajak Bumi dan Bangunan perlu diketahui beberapa macam konsep untuk mempermudah administrasi perpajakannya. Salah satu nya adalah mengenai objek pajak dan subjek pajak. Objek pajak dalam PBB adalah bumi dan/atau bangunan yang dimiliki, dikuasai, dan/atau dimanfaatkan oleh orang pribadi atau badan, kecuali kawasan yang digunakan untuk kegiatan usaha perkebunan, perhutanan, dan pertambangan. Sementara subjek atau wajib pajak dalam PBB adalah orang pribadi atau badan yang secara nyata mempunyai suatu hak atas bumi dan atau memperoleh manfaat atas bumi dan atau memiliki, menguasai dan atau memperoleh manfaat atas bangunan.

Oleh karena itu, kategori pajak ini menjadi kategori pajak yang "gampanggampang susah"pengadministrasiannya. Secara objek pajak, objek pajak PBB bukan objek pajak yang dapat berpindah sehingga relatif mudah untuk diketahui, namun akan menjadi cukup rumit ketika dikaitakan dengan penilaian nilai jual objek pajak, penialaian properti, dan proyeksi investasi. Oleh karena itulah dibutuhkan sumderdaya manusia dengan skill khusus untuk pekerjaan ini.

Beberapa pengalaman daerah di Nusantara yang sudah berusaha melakukan persiapan untuk melaksanakan kebijakan ini menunjukkan bahwa mereka belum siap baik secara aparatur birokrat maupun sumber daya yang lain. Papua Barat merupakan salah satu diantara Provinsi di Indonesia yang harus mempersiapkan daerahnya dalam melaksanakan pelimpahan kewenangan pengelolaan PBB. Beberapa tantangan yang akan dihadapi misalnya yang terjadi di Provinsi Papua Barat dalam mengimplementasikan kebijakan ini.

Regulasi yang sering berubahubah yang membuat daerah sulit untuk menyesuaikan dengan regulasi tersebut. Sumber daya manusia dan fasilitas yang dimiliki Provinsi Papua Barat juga masih sangat terbatas. Luas wilayah dan persebaran penduduk yang tidak merata juga cukup menyulitkan pemungutan pajak, belum lagi budaya sadar pajak yang masih minim.

Demografi wilayah Papua Barat merupakan kepulauan, hal ini tentu saja menyulitkan untuk melakukan penilaian objek pajak bumi dan bangunan serta pemungutan pajaknya. Aspek yang 
memperburuk dan menambah kendala dalam mengimplementasikan kebijakan ini lainnya adalah transportasi yang masih sangat terbatas dalam menghubungkan kabupaten/kota di Papua Barat.

Sementara itu, tidak jauh berbeda dengan Papua Barat, Kutai Kartanegara, sebagai salah satu kabupaten terkaya di Indonesia menilai bahwa kebijakan ini adalah kebijakan yang setengah hati. Dalam undang-undang yang mengatur tentang PBB (UU Nomor 12 Tahun 1994 yang merupakan penyempurnaan Undang-Undang Nomor 12 Tahun 1985) menyebutkan bahwa objek PBB dibagi dalam lima sektor yaitu pedesaan, perkotaan, pertambangan, kehutanan dan perkebunan.

Dengan diberlakukannya UU Nomor 28 Tahun 2009, maka pajak bumi dan bangunan sektor pedesaan dan perkotaan dialihkan menjadi pajak kabupaten/kota yang harus sudah dilaksanakan selambat-lambatnya pada tanggal 13 Desember 2013. Sementara PBB Perkebunan, Perhutanan, dan Pertambangan tetap menjadi pajak pusat dan dikelola pemerintah pusat. Bagi Kutai Kartanegara, banyak faktor-faktor yang harus dipertimbangkan untuk melaksanakan pelimpahan kewenangan pengelolaan PBB P2 ini.

Pertama, biaya koleksi pajak, selama ini setelah dikurangi biaya koleksi seluruh penerimaan pajak PBB P2 masuk ke daerah, sementara setelah adanya kebijakan ini, biaya koleksi dibebankan ke daerah, sehingga pelimpahan kewenangan pengelolaan PBB ini menyisakan biaya koleksi yang juga didaerahkan.

Kedua, mendaerahkan PBB berarti juga mendaerahkan pegawai, padahal masalah besar yang dihadapi daerah dalam masa pelimpahan kewenangan pengelolaan ini adalah membengkaknya jumlah pegawai dan beban belanjanya karena pemindahan pegawai pusat ke daerah.

Ketiga adalah pelimpahan kewenangan pengelolaan PBB ini juga berdampak pada pelimpahan kewenangan pengelolaan perangkat keras (hardware) dan perangkat lunak (software). Tentu saja hal ini harus diikutidengan pemindahan basis data dan juga sumberdaya manusia yang memiliki keahlian di bidang tersebut.

Keempat, pelimpahan kewenangan pengelolaan PBB ditakutkan dapat meningkatkan kesenjangan 
pendapatan antar daerah karena hilangnya unsur sumbangan dan distribusi pendapatan antar daerah.

Dari beberapa pertimbangan tersebut, kebijakan ini dinilai sebagai kebijakan yang setengah hati, terutama bagi Kabupaten Kutai Kartanegara, daerah seolah mendapat angin segar atas adanya pajak baru. Namun bagi beberapa daerah yang tidak memiliki potensi PBB P2 yang besar, hal tersebut memberi kesan sebagai perluasan kewenangan yang kurang menyeluruh. Misalkan saja Kutai Kartanegara yang yang memiliki porsi kecil untuk PBB P2 dibandingkan dengan PBB sektor lain.

Dari pengalaman beberapa daerah diatas, dapat dilihat bahwa sesungguhnya masih banyak daerah yang belum siap baik secara kapasitas maupun kapabilitas. Kebijakan ini seolah menjadi kebijakan yang dipaksakan, dan terlalu memandang sama rata bagi seluruh Kabupaten/Kota yang ada di Indonesia, tanpa melihat kekurangan dan kesejangan sumberdaya yang terjadi terutama bagi daerah di luar Pulau Jawa.

Cukup menarik kemudian membahas persiapan di Kota Yogyakarta, ditinjau dari aspek-aspek yang harus disiapkan menurut Kementrian
Keuangan, Kota Yogyakarta secara formalitas telah memenuhi aspek-aspek tersebut. Dengan adanya Peraturan Daerah Kota Yogyakarta Nomor 2 Tahun 2011 tentang Pajak Bumi dan Bangunan Perdesaan dan Perkotaan serta Peraturan Walikota Nomor 83 Tahun 2011, Kota Yogyakarta telah siap secara landasan legalitas. Begitu juga dengan adanya alokasi anggaran dalam APBD untuk pengalihan PBB. Namun selanjutnya, secara sumberdaya manusia masih juga mengalami kekurangan.

\section{SIMPULAN}

Pada akhirnya kebijakan ini menjadi kebijakan yang perlu dikaji ulang untuk implementasinya. Kesiapan daerah merupakan acuan penting untuk studi implementasi kebijakan pelimpahan kewenangan. Kebijakan ini bisa menjadi kebijakan yang memaksakan diri bagi daerah. Kebijakan yang pada awal tujuannya adalah meningkatkan kemandirian daerah untuk menaikkan pos pendapatan asli daerah justru dapat berbalik menjadi kebijakan yang menjadi sumber pemborosan APBD karena kurang siapnya kapasitas dan kapabilitas daerah dalam menerima kebijakan ini.

Penganggaran yang digunakan untuk tahap persiapan pelimpahan 
kewenangan misalnya, bisa menjadi celah penyimpangan keuangan. Pengadaan barang dan jasa tentu dibutuhkan dalam rangka memenuhi kebutuhan pelaksanaan kebijakan. Namun, standarisasi kebutuhan kebijakan setiap daerah tentunya berbeda-beda, akibatnya tidak terukurnya efisiensi anggaran dan justru dapat menambah beban APBD.

Kesiapan daerah tentunya tidak hanya dari segi anggaran saja, kesiapan dari aspek sumberdaya manusia, sistem informasi pajak, teknologi, peraturan daerah, sosialisasi, dan kerjasama antar lembaga perlu dibangun dan dipastikan kapabilitasny, sehingga dalam melaksanakan kebijakan dapat tercapai efisiensi dan efektifitasnya.

\section{DAFTAR PUSTAKA}

Asian Development Bank. 2010. Startegi Peta Riwayat Pelimpahan Wewenang Pajak Bumi dan Bangunan. Seri Desentralisasi Fiskal di Indonesia, Makalah No. 1 Tahun 2010.

Brotodiharjo, Santoso. 2003. Pengantar Ilmu Hukum Pajak, Edisi Keempat. Bandung: Refika Editama.

Direktorat Pajak Daerah dan Retribusi Daerah, Kementrian Keuangan
Republik Indonesia.Modul Sosialisasi Pengalihan PBB-P2 dan BPHTB menjadi Pajak Daerah.2011.

Mardiasmo. 2006. Perpajakan, Edisi Revisi. Yogyakarta: Penerbit Andi.

Kelly, Roy.1989. Keuangan Pemerintah Daerah di Indonesia (Keuangan Pemerintah Daerah di Indonesia). Jakarta: UI Press.

Seminar Nasional "Implementasi Undang-Undang Nomor 28 Tahun 2009 Tentang Pajak Daerahdan Retribusi Daerah" dilaksanakan di Ballroom Hyatt Regency Hotel Yogyakrata, 6 Maret 2010.

Santosa, Budi. 2011. Ketika Pajak Bumi dan Bangunan sebagai Pajak Daerah.

Syah, Anwar. 1994. The Reform of Intergovernmental Fiscal Relations In Developing And Emerging Market Economices. The World Bank's Policy and research series No. 23, h.2, p.2. dalam Makalah Seri Desentralisasi Fiskal di Indonesia, ADB.

Peraturan Perundang-undangan:

UU Nomor 18 Tahun 1997 tentang Pajak Daerah dan Retribusi Daerah

UU Nomor 25 Tahun 1999 dan UU Nomor 22 Tahun 1999 tentang Pemerintah Daerah

UU Nomor 17 Tahun 2003 tentang Keuangan Negara 
NATAPRAJA Vol. 4 No. 1, Mei 2016

UU Nomor 32 Tahun 2004 tentang Pemerintah Daerah

UU Nomor 28 Tahun 2009, tentang

Pajak dan Retribusi Daerah 